\title{
EFFECT OF POTASSIUM FERTILIZATION ON YIELD AND NUTRITION OF YERBA MATE (Ilex paraguariensis) ${ }^{(1)}$
}

\author{
Delmar Santin $^{(2)}$, Eliziane Luiza Benedetti ${ }^{(3)}$, Nairam Félix de Barros ${ }^{(4)}$, Igor Carvalho de \\ Almeida $^{(5)}$, Greice Pereira Leal ${ }^{(6)}$, Lucas Fontes ${ }^{(5)}$, Júlio César Lima Neves ${ }^{(7)}$, Ivar \\ Wendling $^{(8)}$ \& Carlos Bruno Reissmann ${ }^{(9)}$
}

\begin{abstract}
SUMMARY
Yerba mate (Ilex paraguariensis) is a tree species native to the subtropical regions of South America, and is found in Brazil predominantly in the southern region. Despite the historical importance in this region, so far, studies on crop nutrition to improve yields are scarce. Thus, this study evaluated the effect of potassium rates on $\mathrm{K}$ soil availability, and the yield and nutritional status of yerba mate. The experiment was conducted in São Mateus do Sul, State of Paraná, on a Humox soil, where $\mathrm{K}_{2} \mathrm{O}$ rates of $0,20,40,80,160$, and $320 \mathrm{~kg} \mathrm{ha}^{-1}$ were tested on 7-year-old plantations. The experiment was harvested 24 months after installation by removing approximately $95 \%$ of the canopy that had sprouted from the previous harvest. The soil was evaluated for $K$ availability in the layers 0-10, 0-20, 10-20, and $20-40 \mathrm{~cm}$. The plant parts leaf fresh matter (LM), twigs (TW), thick branches (BR) and commercial yerba mate (COYM), i.e., LM+TW, were analyzed. In addition, the relationship between fresh matter/dry matter (FM/DM) and $\mathrm{K}$ concentration in LM, AG and BR were evaluated. The fertilization increased $\mathrm{K}$ availability in all evaluated soil layers, indicating good mobility of the nutrient even at low rates. Yerba mate responded positively to increasing $\mathrm{K}_{2} \mathrm{O}$ rates with higher yields of all harvested components. The crop proved K-demanding, with a maximum COYM yield of $28.5 \mathrm{t} \mathrm{ha}^{-1}$, when $72 \mathrm{mg} \mathrm{dm}^{-3} \mathrm{~K}$ was available in the 0-20 cm layer. Yerba
\end{abstract}

(1) Received for publication on July 11, 2013 and approved on June 2, 2014.

(2) Pos Doctoral student, Federal University of Santa Catarina. Av. Luiz de Camões, 2090, Bairro Conta Dinheiro. CEP 88520-000 Lages (SC), Brazil, E-mail: desantinflorestal@yahoo.com.br

(3) Professor, Federal Institute of Santa Catarina. Av. Expedicionários, 2150, Bairro Campo da Água Verde. CEP 89460-000 Canoinhas (SC), Brazil. E-mail: elibettiagro@yahoo.com.br

(4) Full Professor, Soil Science Department - DPS, Federal University of Viçosa - UFV. Av. P. H. Rolfs, s/n. CEP 36570-900 Viçosa (MG), Brazil. E-mail: nfbarros@ufv.br

(5) Undergraduate student, UFV. E-mail: igor.almeida@ufv.br, lucas.fontes@ufv.br

(6) Master's degree student, Soil Science and Plant Nutrition Department, Escola Superior de Agricultura "Luiz de Queiroz", ESALQ/USP. Av. Pádua Dias, 11. Caixa Postal 9. CEP 13418-900 Piracicaba (SP), Brazil. E-mail: greiceleal89@gmail.com

(7) Adjunct Professor, DPS, UFV. E-mail: julio_n2003@yahoo.com.br

(8) Researcher, Embrapa Forestry. Estrada da Ribeira, km 111. CEP 83411-000 Colombo (PR), Brazil. E-mail: ivar.wendling@embrapa.br

(9) Professor, Federal University of Paraná. Rua dos Funcionários, 1540, Bairro Juvevê. CEP 80035-050 Curitiba (PR), Brazil. Email: reissman@ufpr.br 
mate in the plant production stage requires soil $\mathrm{K}$ availability at medium to high level; in clayey soil with low $\mathrm{K}$ availability, a rate of $300 \mathrm{~kg} \mathrm{ha}^{-1} \mathrm{~K}_{2} \mathrm{O}$ should be applied at 24 month intervals to obtain high yields. A leaf $K$ concentration of $16.0 \mathrm{~g} \mathrm{ha}^{-1}$ is suitable for yerba mate in the growth stage.

Index terms: soil $\mathrm{K}$ availability, $\mathrm{K}$ mobility in the soil, nutrient use efficiency, nutritional status.

\title{
RESUMO: PRODUÇÃO E NUTRIÇÃO DA ERVA-MATE (Ilex paraguariensis) INFLUENCIADAS PELA ADUBAÇÃO POTÁSSICA
}

\begin{abstract}
A erva-mate (Ilex paraguariensis), espécie arbórea nativa das regiões subtropicais da América do Sul, ocorre no Brasil predominantemente na Região Sul. Apesar da histórica importância da cultura nessa região, até o momento, raros foram os trabalhos realizados sobre sua nutrição no intuito de melhorar a produtividade. Assim, objetivou-se avaliar a influência de doses de Ke sua disponibilidade no solo, na produtividade e no estado nutricional da erva-mate. O experimento foi conduzido em São Mateus do Sul, PR, em um Latossolo Vermelho-Escuro álico, onde se avaliaram as doses 0, 20, 40,80, 160 e $320 \mathrm{~kg} \mathrm{ha}^{-1}$ de $\mathrm{K}_{2} \mathrm{O} \mathrm{em}$ cultivo com sete anos de idade. A colheita, 24 meses após a instalação do experimento, consistiu na remoção de aproximadamente $95 \%$ da copa, que brotou da colheita anterior. Avaliou-se, no solo, a disponibilidade de Knas profundidades de 0-10, 0-20, 10-20 e 20-40 cm. Na planta, avaliaram-se a massa verde de folhas (FO), galhos finos (GF), galhos grossos (GG) e erva-mate comercial (ECOM), correspondente a FO+GF. Foi, também, avaliada a relação entre massa verde/massa seca (MV/MS) e o teor de Knas FO, GF e GG. A adubação elevou a disponibilidade de Kem todas as camadas do solo avaliadas, indicando boa mobilidade do nutriente mesmo em pequenas doses. A erva-mate respondeu positivamente ao aumento das doses de $\mathrm{K}_{2} \mathrm{O}$, com incremento da produtividade de todos os componentes colhidos. A cultura evidenciou-se exigente em $K$, tendo a máxima produção de ECOM de 28,5 $t \mathrm{ha}^{-1}$, quando a disponibilidade do nutriente no solo, na camada de $0-20 \mathrm{~cm}$, era de $72 \mathrm{mg} \mathrm{dm}^{-3}$. A erva-mate em fase de produção requer disponibilidade de $K$ no solo entre o nível médio a alto, e, em solo argiloso e com baixo teor de $\mathrm{K}$ disponivel, a dose de $300 \mathrm{~kg} \mathrm{ha}^{-1}$ de $\mathrm{K}_{2} \mathrm{O}$ deve ser aplicada em intervalo de 24 meses para obtenção de alta produtividade. O teor de $K$ foliar de $16,0 \mathrm{~g} \mathrm{~kg}^{-1}$ é adequado para a cultura da erva-mate em fase de produção.
\end{abstract}

Termos de indexação: disponibilidade de potássio no solo, mobilidade de potássio no solo, eficiência de uso do nutriente, estado nutricional.

\section{INTRODUCTION}

Yerba mate (Ilex paraguariensis), a long-living perennial arboreal species (Carvalho, 2003), is native to the subtropical regions of South America (Oliveira \& Rota, 1985) and in Brazil it occurs naturally in acid soils with low exchangeable cations, mainly in the southern region (Carvalho, 2003). It is cultivated mostly on small and medium-sized farms and, until recently, accounted for the income of thousands of small farmers (Gazeta..., 1999). However, the reduction of the average national yield from $17.3 \mathrm{tha}^{-1}$ in 1990 to $6.7 \mathrm{t} \mathrm{ha}^{-1}$ in 2012 (IBGE, 2012), indicates that the crop is in decline.

Research has shown that yerba mate can be classified as healthy food with functional properties for the human body (Gugliucci, 1996; Mejía et al., 2010; Berté et al., 2011). This fact, along with the increasing world population, is expected to stimulate a rising demand for raw material of this crop. However, little advance has been observed in research on the production system in Brazil, which could affect the economic viability of the crop in the medium term.

The yield reduction of more than $60 \%$ over the past two decades is a consequence of the poaching system that is still predominant and the low technology level of cultivation. Yerba mate occurs naturally in the shadow, in the lower forest strata (Castella \& Britez, 2004), but the presence of stomata on the leaf underside (Rakocevic et al., 2011) allows cultivation in shady as well as sunny environments. When the exploitation of yerba mate occurred predominantly in native herb fields, the interval between harvests ranged from 36 to 48 months. However, with the reduction in area of these herb fields and the adoption of plantations, the harvest interval was gradually reduced to around 24 months.

Since the harvest product of yerba mate consists predominantly of leaves, twigs, buds and seeds, the amount of exported nutrients is high (Reissmann et al., 1985). This fact, together with the increased 
intensity of harvesting in the last decades, and considering that the replenishment of the nutrients exported in the harvested crops is still a rare practice, the current production system is unsustainable.

Of all nutrients, $\mathrm{K}$ is the second most exported at harvest. Berger (2006) assessed the nutrient concentration in leaves+twigs, wood, bark, residue, and root of adult herb plants and found that, except in the bark, $\mathrm{K}$ was the second most exported nutrient, in particular in the leaf+twig component, with $122 \mathrm{~kg} \mathrm{ha}^{-1} \mathrm{~K}$. The major K export at harvest explains the response to $\mathrm{K}$ fertilization of yerba mate in some studies (Lourenço et al., 1999; Pandolfo et al., 2003).

Potassium is transported to the root surface predominantly by diffusion and mass flow mechanisms (Oliveira et al., 2004; Ernani et al., 2007a). In the soil, the rate of $\mathrm{K}$ transport in the deeper layers is intermediate to that of $\mathrm{N}$ and $\mathrm{P}$ (Ernani et al., 2007b) and is determined by the amount of water leaching through the profile and the nutrient concentration in the soil solution (Ernani et al., 2007b; Neves et al., 2009), but is intensified in sandy (Werle et al., 2008) and low CEC soils (Ernani et al., 2007a). Thus, in soils with these properties split applications are recommended, to minimize K leaching losses (Raij, 1991). The application of rates compatible with the crop fertilizer requirements also helps to reduce $\mathrm{K}$ losses (Ernani et al., 2007a). For Kaminski et al. (2010), K fertilization programs should establish a sufficiency level, based on which the recommended rate would meet the crop requirements, in agreement with the amount exported by the crop, avoiding the establishment of broad bands of $\mathrm{K}$ availability for fertilizer recommendation. Adopting these measures would prevent the movement of $\mathrm{K}$ to deeper soil layers.

The scarce reports on fertilization of herb fields impair the establishment of crop-specific nutritional needs and fertilization recommendation. Given the above, the objective was to evaluate the effect of $\mathrm{K}$ fertilization rates on yerba mate yield, soil Kavailability and the nutritional status of plants in the herb field.

\section{MATERIAL AND METHODS}

The experiment was conducted in São Mateus do Sul, PR, on the second Paraná Plateau (longitude $50^{\circ} 32^{\prime} \mathrm{W}$, latitude $25^{\circ} 54^{\prime} \mathrm{S}, 789 \mathrm{~m}$ asl). The regional climate is temperate $(\mathrm{Cfb})$, with average annual rainfall between 1,600-1,800 mm (IAPAR, 1994). The local soil, a Humox, has a low $\mathrm{pH}$ and clayey texture (Table 1).

After removing part of the forest, sparse individuals of native yerba mate, Araucaria, walnut and cinnamon remained in the area. In 2001, yerba mate was planted at $2 \times 2 \mathrm{~m}$ spacing, using seedlings derived from seeds collected from local mother plants.

Prior to the experiment, the first harvest of yerba mate (formation pruning) was performed approximately $1 \mathrm{~m}$ above the ground 24 months after planting, and the other harvests were carried out every 18 months. No liming and mineral or organic fertilization had ever been applied in the area. In January 2009, the experiment was initiated, and the herb field was mechanically weeded in September, January and April of each year.

Treatments consisting of six $\mathrm{K}_{2} \mathrm{O}$ rates were arranged in a randomized block design with five replications. Each experimental unit consisted of 10 healthy plants, separated from the neighboring plot by two border rows.

Rates of $0,20,40,80,160$, and $320 \mathrm{~kg} \mathrm{ha}^{-1} \mathrm{~K}_{2} \mathrm{O}$ in the source potassium chloride were applied. At the beginning of the experiment, $1 \mathrm{t} \mathrm{ha}^{-1}$ of dolomitic limestone was applied to the soil surface on the entire area, as recommended by CQFSRS/SC (2004). As additional fertilizers, $\mathrm{N}$ and $\mathrm{P}$ were applied $\left(80 \mathrm{~kg} \mathrm{ha}^{-1}\right.$ of $\mathrm{N}$ and $\mathrm{P}_{2} \mathrm{O}_{5}$, respectively), in the form of urea and triple superphosphate.

The $\mathrm{K}_{2} \mathrm{O}$ rates and additional fertilizers were applied to the soil surface in the area under the tree canopies without incorporation into the soil, at the beginning of January and September. The $\mathrm{K}_{2} \mathrm{O}$ rates and additional fertilizers were applied three times (Table 2).

At harvest, a composite soil sample was prepared from 15 single samples collected at three points from under the canopy of five plants in the layers 0-10, 10-20 and 20-40 cm of each plot. Samples from the 0-10 cm layer were collected with a spade, in bands (width $20 \mathrm{~cm} \times$ thickness $3 \mathrm{~cm}$ ). Then, from the center of the same points, soil was collected with a Dutch auger from the layers underneath. After air-drying and sieving through a $2 \mathrm{~mm}$ mesh, the samples were analyzed to determine the $\mathrm{K}$ availability, extracted with Mehlich-1 (De Filippo \& Ribeiro, 1997) and determined by flame photometry (AOAC, 1975). From the data of the $0-10$ and $10-20 \mathrm{~cm}$ layers, the $\mathrm{K}$ availability in the $0-20 \mathrm{~cm}$ layer was calculated.

Before harvest, shoots were collected from the middle third of the canopy, for chemical analysis of $\mathrm{K}$ and to determine the relationship between fresh and dry matter of leaves and twigs. At harvest, one representative sample of thick branches per plot was taken for the same measurements. The shoot sample was separated into leaves and twigs immediately after harvest. After quantifying the fresh matter, the plant material was washed, dried at $65{ }^{\circ} \mathrm{C}$ to constant weight, the dry weight determined and the material of each sample ground in a Willey mill with a $0.5 \mathrm{~mm}$ sieve for subsequent chemical analysis of $K$. Potassium was extracted by nitropercloric digestion from the plant material and determined by flame photometry (Tedesco et al., 1995). 
The effect of fertilization was evaluated 24 months after the beginning of the experiment (Table 2). At harvest, approximately $95 \%$ of the fresh matter grown after the previous harvest was removed, and the material was separated in commercial yerba mate $(\mathrm{COYM}=$ leaves+twigs) and thick branches $(\mathrm{BR})$, and the amount of fresh matter of both determined. Plant material with a diameter smaller than $7 \mathrm{~mm}$, approximately, was considered twigs (TW), and above this diameter branches (BR).

The fresh matter yield of the components leaves (LM), twig (TW), thick branches (BR) and commercial yerba mate (COYM) were determined. For COYM, the effect of the fertilizer rate on yield was also calculated (COYM.PID = total yield minus yield of unfertilized plot). The K use efficiency (KUE) was calculated as the ratio between dry matter (DM) of the harvested plant components (COYM+BR) and cumulative nutrient concentration $\left(\mathrm{kg} \mathrm{DM} \mathrm{kg}^{-1} \mathrm{~K}\right)$ (Barros et al., 1986). The K recovery rate from fertilizer by the plant (pl.RR) was computed by the formula:

Table 1. Clay content and soil properties in the 0-20 cm layer at the experimental site

\begin{tabular}{lr}
\hline Attribute & Value \\
\hline Clay $\left(\mathrm{g} \mathrm{kg}^{-1}\right)$ & 760.00 \\
Organic carbon $\left(\mathrm{g} \mathrm{kg}^{-1}\right)$ & 29.79 \\
$\mathrm{pH}\left(\mathrm{H}_{2} \mathrm{O}\right)$ & 3.70 \\
$\mathrm{Al}^{3+}\left(\mathrm{cmol}_{\mathrm{c}} \mathrm{dm}^{-3}\right)$ & 4.79 \\
$\mathrm{H}+\mathrm{Al}\left(\mathrm{cmol}_{\mathrm{c}} \mathrm{dm}^{-3}\right)$ & 16.33 \\
$\mathrm{CEC}$ & 17.68 \\
$\mathrm{~V}(\%)$ & 7.64 \\
$\mathrm{~m}(\%)$ & 78.01 \\
$\mathrm{P}\left(\mathrm{mg} \mathrm{dm}^{-3}\right)$ & 1.50 \\
$\mathrm{~K}\left(\mathrm{mg} \mathrm{dm}^{-3}\right)$ & 54.90 \\
$\mathrm{Ca}{ }^{2+}\left(\mathrm{cmol}_{\mathrm{c}} \mathrm{dm}^{-3}\right)$ & 0.87 \\
$\mathrm{Mg}{ }^{2+}\left(\mathrm{cmol}_{\mathrm{c}} \mathrm{dm}^{-3}\right)$ & 0.34 \\
$\mathrm{~S}\left(\mathrm{mg} \mathrm{dm}^{-3}\right)$ & 7.56 \\
$\mathrm{Zn}\left(\mathrm{mg} \mathrm{dm}^{-3}\right)$ & 2.50 \\
$\mathrm{Cu}\left(\mathrm{mg} \mathrm{dm}^{-3}\right)$ & 13.10 \\
$\mathrm{~B}\left(\mathrm{mg} \mathrm{dm}^{-3}\right)$ & 0.53 \\
$\mathrm{Mn}\left(\mathrm{mg} \mathrm{dm}^{-3}\right)$ & 29.00 \\
$\mathrm{Fe}\left(\mathrm{mg} \mathrm{dm}^{-3}\right)$ & 71.00 \\
\hline
\end{tabular}

Mehlich-1 (0.05 mol L-1 $\left.\mathrm{HCl}+0.0125 \mathrm{~mol} \mathrm{~L}^{-1} \mathrm{H}_{2} \mathrm{SO}_{4}\right)$ : P, K, Fe, $\mathrm{Mn}, \mathrm{Cu}$, and $\mathrm{Zn}$; $\mathrm{KCl} 1 \mathrm{~mol} \mathrm{~L}^{-1}$ : $\mathrm{Ca}, \mathrm{Mg}$ and $\mathrm{Al}$; Calcination and $\mathrm{HCl}$ solution: $\mathrm{B}$; and calcium phosphate: $\mathrm{S}$.

$$
\mathrm{pl} . \mathrm{RR}=\left(\frac{\text { KCont } . \mathrm{f} . \mathrm{pl}-\mathrm{KCont} \cdot \mathrm{unf} . \mathrm{pl}}{\mathrm{K} \cdot \mathrm{R} .}\right) \times 100,
$$

where pl.RR = plant recovery rate of $\mathrm{K}$ from fertilizer; KCont.f.pl $=\mathrm{K}$ concentration of components $(\mathrm{COYM}+\mathrm{BR})$ of fertilized plants; KCont.unf.pl $=\mathrm{K}$ concentration of unfertilized plants; and $\mathrm{K} . \mathrm{R}=\mathrm{K}$ rate applied. The ratio between fresh and dried matter (FM/DM) was calculated for LM (LM.FM/DM), TW (TW.FM/DM) and COYM (COYM.FM/DM).

Data were evaluated by ANOVA and the effect of $\mathrm{K}$ was estimated by regression. For $\mathrm{K}$ in the soil, in the partitioning of the interaction between the factors plot (rate) and subplot (layer) to evaluate the effect of the subplot within the plot, the mean square was adopted as error of the combined residue and the respective number of degrees of freedom, according to Satterthwaite (1946).

\section{RESULTS AND DISCUSSION}

\section{Available potassium in soil}

The concentration of available $\mathrm{K}$ in the soil increased linearly in all layers with increasing $\mathrm{K}$ fertilizer rate. Potassium availability increases most in the $0-10 \mathrm{~cm}$ layer (Figure 1a), where the increase of available $\mathrm{K}$ was $37 \mathrm{mg} \mathrm{dm}{ }^{-3}$ at the highest rate (320 kg ha ${ }^{-1} \mathrm{~K}_{2} \mathrm{O}$ ), (Figure 1a). The smallest increase in $\mathrm{K}$ concentration $\left(9 \mathrm{mg} \mathrm{dm}^{-3}\right)$ at the highest rate was found in the $20-40 \mathrm{~cm}$ layer. In the intermediate layers $0-20$ and $10-20 \mathrm{~cm}$, soil $\mathrm{K}$ increased by 25 and $14 \mathrm{mg} \mathrm{dm}^{-3}$, respectively.

The increase in $\mathrm{K}$ concentration in deeper layers, even in the $20-40 \mathrm{~cm}$ layer and at the lowest rates (20 and $40 \mathrm{~kg} \mathrm{ha}^{-1} \mathrm{~K}_{2} \mathrm{O}$ ), may have been especially favored by high soil acidity and high annual rainfall in the region. Although the soil CEC can be considered high (CQFSRS/SC, 2004), only $\mathrm{Al}^{3+}$ occupied the major part of the exchange sites (Table 1).

The increase in $\mathrm{K}$ availability was linear even in the deeper layers (Figure 1d), due to a higher K concentration in the soil solution after $\mathrm{K}$ fertilization, indicating the vertical mobility of $\mathrm{K}$ in the soil (Rosolem et al., 2006; Neves et al., 2009). Therefore, although the soil was very clayey with high CEC, the movement of $\mathrm{K}$ to the deeper layers was significant.

Table 2. Splitting and time of fertilizer application and timing of yerba mate harvest

\begin{tabular}{|c|c|c|c|c|c|c|}
\hline \multicolumn{6}{|c|}{ Subdivision and time of application of $\mathrm{K}_{2} \mathrm{O}$ rates and additional fertilizers ${ }^{(1)}$} & \multirow{2}{*}{ Harvest } \\
\hline \multicolumn{2}{|c|}{$1^{\text {st }}$ portion } & \multicolumn{2}{|c|}{$2^{\text {nd }}$ portion } & \multicolumn{2}{|c|}{$3^{\text {rd }}$ portion } & \\
\hline $\mathrm{K}_{2} \mathrm{O}$ rate & Time & $\mathrm{K}_{2} \mathrm{O}$ rate & Time & $\mathrm{K}_{2} \mathrm{O}$ rate & Time & Time \\
\hline $33.3 \%$ & Jan/2009 & $33.3 \%$ & Sep/2009 & $33.3 \%$ & Sep/2010 & Jan/2011 \\
\hline
\end{tabular}

(1) A supplementary fertilizer rate $\left(80 \mathrm{~kg} \mathrm{ha}^{-1}\right.$ of $\mathrm{N}$ and $\left.\mathrm{P}_{2} \mathrm{O}_{5}\right)$ was split equally to the $\mathrm{K}_{2} \mathrm{O}$ rates. 

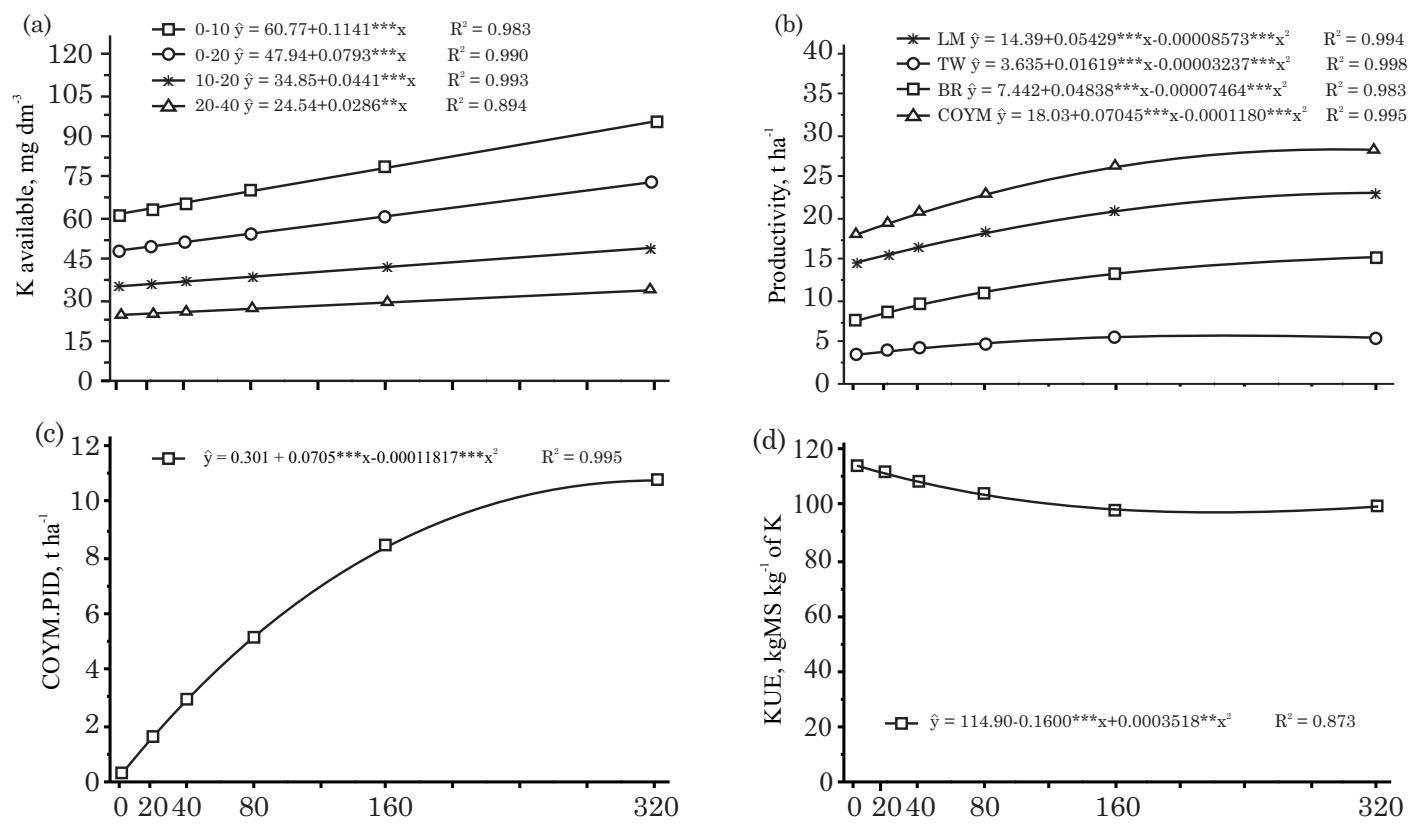

Rate of $\mathrm{K}_{2} \mathrm{O}$, $\mathrm{kg} \mathrm{ha}^{-1}$

Figure 1. Availability of $\mathrm{K}$ in the soil in the layers 0-10, 0-20, 10-20, and 20-40 cm (a); fresh leaf matter yield (LM), twigs (TW), thick branches (BR) and commercial yerba mate (COYM) (b); COYM yield affected by the rate (COYM.PID) (c); and K use efficiency (KUE) in K-fertilized yerba mate (d). ** and *** significant at 1 and $0.1 \%$, respectively.

This fact would probably not have been detected if the liming rate had been higher, which would have caused the neutralization of exchangeable $\mathrm{Al}$ and $\mathrm{H}$ and occupation of sites by K. In soils with high acidity where $\mathrm{Al}^{3+}$ concentrations are high, this ion is rather adsorbed by negative charges than by other lower valence cations, favoring $\mathrm{K}$ mobility in the soil profile (Bissani et al., 2004). In addition, the neutralization of part of the exchangeable $\mathrm{H}$ and $\mathrm{Al}$ by liming could raise the effective CEC (Albuquerque et al., 2000) and favor $\mathrm{K}$ adsorption and consequently reduce its mobility in the soil profile. Another practice to reduce $\mathrm{K}$ movement would be to increase the splitting of fertilization.

\section{Yield and $\mathrm{K}$ nutritional status of yerba mate}

Yerba mate responded positively to K fertilization with yield increases in all harvested plant components, with an increase in COYM in the order of $58 \%$. Highest yields of $23.0,5.7,15.3$, and $28.5 \mathrm{t} \mathrm{ha}^{-1}$, respectively, of LM, FG, BR, and COYM were obtained with $\mathrm{K}$ fertilizer rates of $317,250,320$, and 298 $\mathrm{kg} \mathrm{ha}^{-1} \mathrm{~K}_{2} \mathrm{O}$ (Figure $1 \mathrm{~b}$ ).

The COYM yield was much higher than the national average yield of $6.7 \mathrm{t} \mathrm{ha}^{-1}$ in 2012 (IBGE, 2012). In Argentina, in low-technology cultivation systems, the average annual yield is $3.0 \mathrm{t} \mathrm{ha}^{-1}$, but higher than $12.0 \mathrm{t} \mathrm{ha}^{-1} \mathrm{yr}^{-1}$ in those with high technology (Montechiesi, 2008). The maximum COYM yield was $28.5 \mathrm{t} \mathrm{ha}^{-1}$, exceeding the national average by $325 \%$ and was $482 \%$ higher than the state average of Paraná (IBGE, 2012). This result demonstrates the importance of a good nutritional management for increased domestic yerba mate yield.

In general, high $\mathrm{K}_{2} \mathrm{O}$ rates were required to maximize the yield of each component. A linear yield increase with annual rates of $120 \mathrm{~kg} \mathrm{ha}^{-1} \mathrm{~K}_{2} \mathrm{O}$ was obtained in 6-year-old herb fields (Lourenço et al., 1999). After nine years, when the K soil concentration was below $120 \mathrm{mg} \mathrm{dm}^{-3}$, the annual application of $143 \mathrm{~kg} \mathrm{ha}^{-1} \mathrm{~K}_{2} \mathrm{O}$ resulted in fresh matter yield close to the maximum response (Pandolfo et al., 2003). The COYM yield (Figure $1 \mathrm{~b}$ ) was highest when the $\mathrm{K}$ concentration in the soil layers $0-10$ and $0-20 \mathrm{~cm}$ was 95 and $72 \mathrm{mg} \mathrm{dm}^{-3}$, respectively, which was considered high and medium (CQFSRS/SC, 2004). Thus, even where yerba mate occurs naturally in low fertility soils (Carvalho, 2003), high levels of soil K availability are required to reach the maximum production capacity.

The COYM yield was influenced by the $\mathrm{K}$ fertilizer rate (COYM.PID) (Figure 1c) and use efficiency (KUE) (Figure 1d) and was positively and negatively influenced by the nutrient levels, respectively. At a $\mathrm{K}_{2} \mathrm{O}$ rate of $298 \mathrm{~kg} \mathrm{ha}^{-1}$, COYM.PID $10.8 \mathrm{t} \mathrm{ha}^{-1}$ was highest (Figure 1c) and KUE lowest (97 kg DM kg-1 K) at $227 \mathrm{~kg} \mathrm{ha}^{-1} \mathrm{~K}_{2} \mathrm{O}$ (Figure 1d). Therefore, yields are maximized when KUE is close to $100 \mathrm{~kg} \mathrm{DM} \mathrm{kg}^{-1} \mathrm{~K}$ contained in the harvested material. The use of low nutrient rates in low-fertility soils leads to a linear 
yield response and a high nutrient use efficiency by the plant (van Keulen, 1982). At higher rates or when fertility is high, the nutrient use efficiency is reduced (Epstein \& Bloom, 2004). Nutrient absorption in addition to the need for biochemical processes can result in toxicity or other nutrient imbalances (van Keulen, 1982; Hawkesford et al., 2012) reducing yields, as apparently occurred in this study at the highest $\mathrm{K}$ rates.

The ratio between fresh and dry matter (FM/DM) of LM (LM.FM/DM) and COYM (COYM.FM/DM) was affected by the fertilizer rate and was positively linearly related with the $\mathrm{K}$ rates. At a rate that maximized yield and COYM, the values of the relationship LM.FM/COYM.FM and FM/DM were, respectively, 3.06 and 3.13. For TW (TW.FM/DM), this relationship was however not affected by $\mathrm{K}$ rates, with a mean value of 3.55 (Table 3 ).

The records regarding FM/DM in yerba mate for LM range from 2.41 (Campos, 1991) to 3.40 (Santin, 2008), in TW from 2.38 to 2.54 (Campos, 1991) and COYM from 1.90 (Reissmann et al., 1985) to 2.59 (Campos, 1991). The values of the FM/DM ratio found here are therefore higher than the commonly observed for yerba mate. However, the studies of Campos (1991) and Reissmann et al. (1985) were carried out in unfertilized herb fields. Thus, the values presented here can be assumed as ideal for representing the condition of maximum yerba mate yield in relation to $\mathrm{K}$ rates.

The K concentration of all components (Figure 2a), the K concentration in COYM and in BR (Figure 2b), as well as the plant recovery rate of $K$ (pl.RR) (Figure $2 \mathrm{~d}$ ) were affected by the $\mathrm{K}_{2} \mathrm{O}$ rate. The $\mathrm{K}$ concentration in TW and $\mathrm{BR}$ was maximum at rates of 258 and $260 \mathrm{~kg} \mathrm{ha}^{-1} \mathrm{~K}_{2} \mathrm{O}$, with 13.9 and $9.1 \mathrm{~g} \mathrm{~kg}^{-1}$, respectively. The leaf $\mathrm{K}$ concentration was linear with increasing $\mathrm{K}_{2} \mathrm{O}$ rates, with a maximum of $16.2 \mathrm{~g} \mathrm{~kg}^{-1}$ at the highest rate tested (Figure 2a).

The rate that obtained the highest COYM, the $\mathrm{K}$ concentration in COYM and BR was 141 and $56 \mathrm{~kg}$ ha $^{-1} \mathrm{~K}$, respectively (Figure $3 \mathrm{~b}$ ). When aside from COYM, BR is also removed from the area, $197 \mathrm{~kg} \mathrm{ha}^{-1} \mathrm{~K}$ would be exported. However, under this same condition $\left(\mathrm{K}_{2} \mathrm{O}\right.$ rate of $\left.298 \mathrm{~kg} \mathrm{ha}^{-1}\right)$, the distribution of the $\mathrm{K}$ concentration and matter of each component varies

Table 3. Regression equation and mean values of the ratio between fresh and dry matter (FM/DM) of K-fertilized yerba mate

\begin{tabular}{llc}
\hline Variable $^{(1)}$ & \multicolumn{1}{c}{ Equation } & $\mathbf{R}^{2}$ \\
\hline LM.FM/DM & $\hat{y}=2.804+0.0008538^{* *} \mathrm{x}$ & 0.770 \\
TW.FM/DM & $\hat{y}=\bar{y}=3.550$ & - \\
COYM.FM/DM & $\hat{y}=2.891+0.0008214^{* * *} \mathrm{x}$ & 0.810 \\
\hline
\end{tabular}

(1) Leaf (LM), commercial yerba mate (COYM) and twigs (TW).

$* *$ and $* * *$ significant at 1 and $0.1 \%$, respectively. according to the concentration of this nutrient in plant tissue. Comparing the distribution of fresh matter produced with the K concentration of each component harvested, the percentage $\mathrm{K}$ concentration of TW and BR tends to decrease compared to the fresh matter. On the other hand, the percentage $\mathrm{K}$ concentration of LM increases compared to fresh matter (Figure 2d). Reissmann et al. (1985) had pointed out the significant nutrient loss from the area at mate harvest. When thick branches left over from the harvest are also removed from the area, the fertilizer replenishment should take an increase in the $\mathrm{K}$ rate into account (Figure 2d) for a harvest interval of 24 months.

The recovery rate of the plant $\mathrm{K}$ (pl.RR) decreased with increasing fertilizer rates. The $\mathrm{pl}$.RR was lowest $(29.2 \%)$ at a rate of $316 \mathrm{~kg} \mathrm{ha}^{-1} \mathrm{~K}_{2} \mathrm{O}$. The pl.RR may be affected, among other factors, by fertilization and plant age (Santos, 2002), and decreased with increasing fertilizer rates (Teixeira et al., 2002) and was higher, the higher plant growth and the larger the root system (Prezotti, 2001; Rosa, 2002). The reduction of pl.RR (Figure 2c) at increasing rates reflects the reduction in KUE with increased plant nutrient availability (Epstein \& Bloom, 2004), as occurred in this study (Figure 1d).

Higher K concentrations in the leaves than in thick branches and twigs are generally observed in tree species, because in this tissue the metabolic processes are most intense (Epstein \& Bloom, 2004). The increase in leaf $\mathrm{K}$ concentration and COYM yield, in response to fertilization, signals the need for $K$ fertilization in plantations of yerba mate (Figure 2). The leaf $\mathrm{K}$ concentration that induced the highest COYM yield was $15.9 \mathrm{~g} \mathrm{~kg}^{-1}$. In the literature, leaf $\mathrm{K}$ concentrations from $5.4 \mathrm{~g} \mathrm{~kg}^{-1}$ (Jacques et al., 2007) to $20.8 \mathrm{~g} \mathrm{~kg}^{-1}$ (Radomski et al., 1992) are reported for yerba mate. In experiments after six years of successive $\mathrm{K}$ fertilizer applications and harvests, Pandolfo et al. (2003) found a mean leaf K concentration of $17.4 \mathrm{~g} \mathrm{~kg}^{-1}$ which is closest to that obtained in this study at the rate for maximum COYM yield.

For the same species, a $\mathrm{K}$ concentration in TW from $9.9 \mathrm{~g} \mathrm{~kg}^{-1}$ (Reissmann et al., 1983) to $13.4 \mathrm{~g} \mathrm{~kg}^{-1}$ was observed (Reissmann et al., 1985) and in BR, from $5.0 \mathrm{~g} \mathrm{~kg}^{-1}$ (Campos, 1991) to $9.6 \mathrm{~g} \mathrm{~kg}^{-1}$ (Berger, 2006). In this study, the rate at which COYM yield is maximized ( $\left.298 \mathrm{~kg} \mathrm{ha}^{-1} \mathrm{~K}_{2} \mathrm{O}\right)$, the $\mathrm{K}$ concentration in FG and BR was, respectively, 13.8 and $9.0 \mathrm{~g} \mathrm{~kg}^{-1}$. For $\mathrm{BR}$, the $\mathrm{K}$ concentration was higher than what is normally found in yerba mate. In the few studies addressing $\mathrm{K}$ concentration in $\mathrm{BR}$, such as those of Campos (1991) and Berger (2006), values were measured on unfertilized herb fields, where soil $\mathrm{K}$ availability was possibly below the crop requirement. Thus, the K concentrations in BR in this study can be considered ideal. 

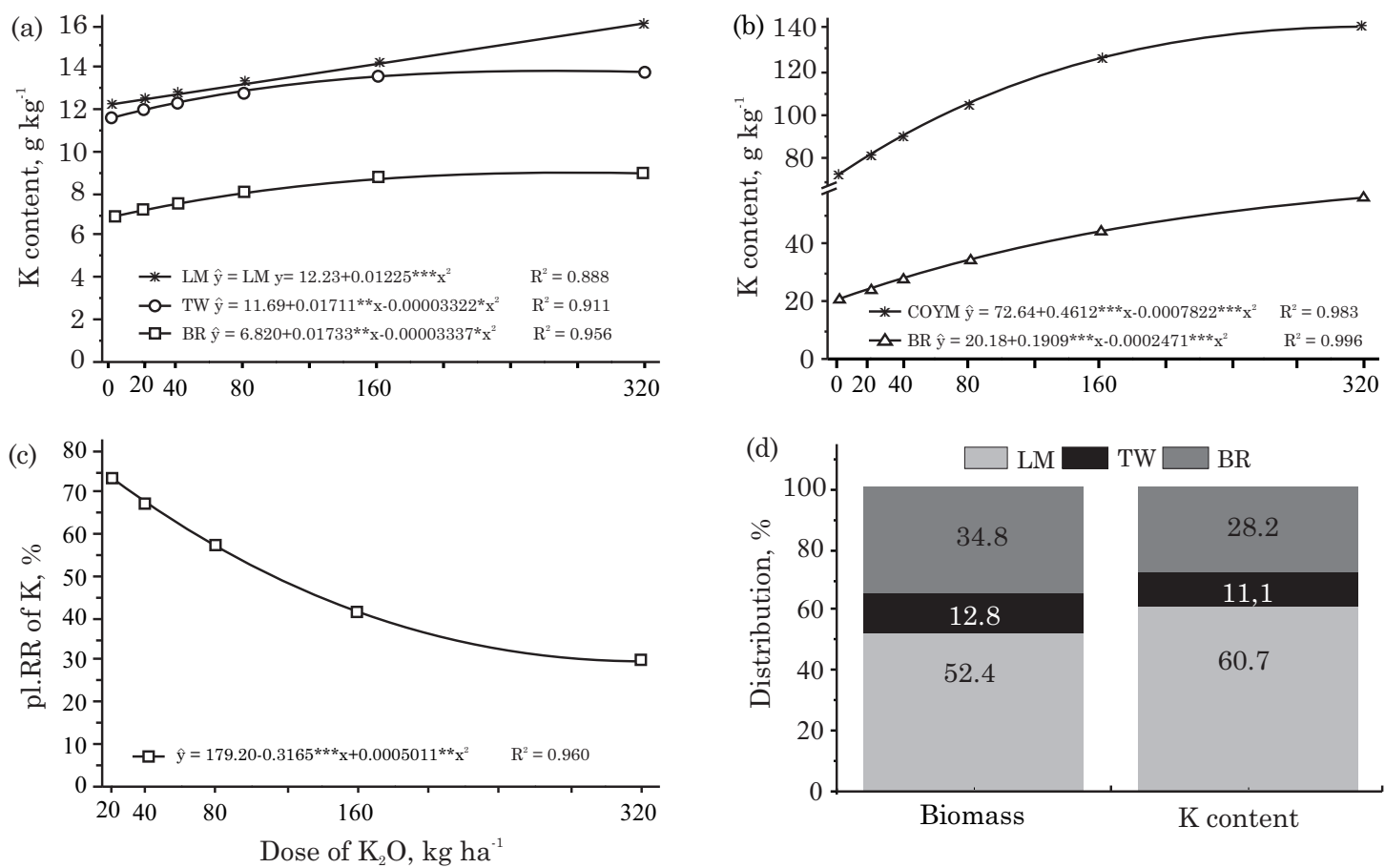

Figure 2. Potassium leaf concentration (LM), twigs (TW) and thick branches (BR) (a); K concentration in commercial yerba mate (COYM) and in BR (b); plant $\mathrm{K}$ recovery rate (pl.RR) (c); and yield distribution and $\mathrm{K}$ concentration in $\mathrm{LM}$, TW and BR at a rate of $298 \mathrm{~kg} \mathrm{ha}^{-1} \mathrm{~K}_{2} \mathrm{O} \mathrm{K}$-fertilized yerba mate (d). *, ** and **** significant at 5, 1 and $0.1 \%$, respectively.

\section{CONCLUSIONS}

1. The soil $\mathrm{K}$ availability for yerba mate in the growth stage should be $120 \mathrm{mg} \mathrm{dm}^{-3}$ in the $0-10 \mathrm{~cm}$ soil layer, and $80 \mathrm{mg} \mathrm{dm}^{-3} \mathrm{~K}$ in the $0-20 \mathrm{~cm}$ layer.

2. Yerba mate in the growth stage, cultivated on clayey soil with low $\mathrm{K}$ availability, reached highest yields when fertilized with $300 \mathrm{~kg} \mathrm{ha}^{-1} \mathrm{~K}_{2} \mathrm{O}$ applied in 24-month intervals.

3. Thick branches export large amounts of $\mathrm{K}$, and when removed from the area, maintenance fertilization area must be increased by $30 \%$.

4. Potassium fertilization barely influences the ratio of fresh/dry matter of commercial yerba mate and a leaf $\mathrm{K}$ concentration of $16.0 \mathrm{~g} \mathrm{~kg}^{-1}$ is suitable for the crop in the growth stage.

\section{ACKNOWLDEGEMENTS}

The authors thank the Agropecuária Vier Ltda and Baldo S.A. in São Mateus do Sul, PR, and are indebted to Embrapa Florestas, Colombo, PR, the Soil Science Department of the Federal University of Viçosa and the National Council for Scientific and Technological Development (CNPq) for funding this research.

\section{LITERATURE CITED}

ALBUQUERQUE, J.A.; BAYER, C.; ERNANI, P.R. \& FONTANA, E.C. Propriedades físicas e eletroquímicas de um Latossolo Bruno afetadas pela calagem. R. Bras. Ci. Solo, 24:295-300, 2000.

ASSOCIATIONS OF OFFICIAL ANALYTICAL CHEMISTS AOAC. Official methods of analysis of the Associations of Official Analytical Chemists. 12.ed. Washington, D.C., 1975. 1024p.

BARROS, N.F.; NOVAIS, R.F.; CARMO, D.N. \& NEVES, J.C.L. Classificação nutricional de sítios florestais - Descrição de uma metodologia. R. Árvore, 10:112-120, 1986.

BERGER, G. Biomassa e nutrientes em plantios de ervamate (Ilex paraguariensis A. St. Hil.) no município de Nova Prata, RS. Santa Maria, Universidade Federal de Santa Maria, 2006. 93p. (Dissertação de Mestrado)

BERTÉ, K.; RUCKER, N. \& RIBANI, R.H. Yerba mate Ilex paraguariensis A. St.-Hil. Phyt., 9:180-184, 2011.

BISSANI, C.A; MEURER, E.J. \& BOHNEN, H. Solos ácidos e solos afetados por sais. In: MEURER, E.J., ed. Fundamentos de química do solo. 2.ed. Porto Alegre, Geneses, 2004. p.181-205.

CAMPOS, M.A.A. Balanço de biomassa e nutrientes em povoamentos de Ilex paraguariensis. Avaliação na safra e na safrinha. Curitiba, Universidade Federal do Paraná, 1991. 107p. (Dissertação de Mestrado) 
CARVALHO, P.H.R. Espécies arbóreas brasileiras. Brasília, Embrapa Informação Tecnológica; Colombo, Embrapa Florestas, 2003. 1039p.

CASTELLA, P.R. \& BRITEZ, R.M., orgs. A floresta com araucária no Paraná: Conservação e diagnóstico dos remanescentes florestais. Brasília, Ministério do Meio Ambiente, 2004. 233p.

COMISSÃO DE QUÍMICA E FERTILIDADE DO SOLO . CQFSRS/SC. Manual de adubação e calagem para os Estados do Rio Grande do Sul e de Santa Catarina. 10.ed. Porto Alegre, SBCS - Núcleo Regional Sul/UFRGS, 2004. 400p.

DE FILIPPO, B.V. \& RIBEIRO, A.C. Análise química do solo; metodologia. Viçosa, MG, Universidade Federal de Viçosa, 1997. 26p. (Boletim de Extensão, 29)

EPSTEIN, E. \& BLOOM, A.J. Nutrição mineral de plantas: Princípios e perspectivas. 2.ed. Londrina, Planta, 2004. 403p.

ERNANI, P.R.; ALMEIDA, J.A. \& SANTOS, F.C. Potássio. In: NOVAIS, R.F.; ALVAREZ V., V.H.; BARROS, N.F.; FONTES, R.L.F.; CANTARUTTI, R.B. \& NEVES, J.C.L., eds. Fertilidade solo. Viçosa, MG, Sociedade Brasileira de Ciência Solo, 2007a. p.551-594.

ERNANI, P.R.; BAYER, C.; ALMEIDA, J.A. \& CASSOL, P.C. Mobilidade vertical de cátions influenciada pelo método de aplicação de cloreto de potássio em solos com carga variável. R. Bras. Ci. Solo, 31:393-402, 2007b.

GAZETA GRUPO DE COMUNICAÇÕES. Anuário Brasileiro da Erva-mate 1999. Santa Cruz do Sul, Pallotti, 1999. $64 \mathrm{p}$.

GUGLIUCCI, A. Antioxidant effects of Ilex paraguariensis: induction of decreased oxidability of human LDL in vivo. Biochem. Biophys. Res. Commun., 2:338-344, 1996.

HAWKESFORD, M.; HORST, W.; KICHEY, T.; LAMBERS, H.; SCHJOERRING, J.; MØLLER, I.S. \& WHITE, P. Functions of macronutrients. In: MARSCHNER, P., ed. Mineral nutrition of higher plants. 3.ed. Oxford, Academic Press, 2012. p.135-189.

INSTITUTO AGRONÔMICO DO PARANÁ - IAPAR. Cartas climáticas básicas do Estado do Paraná. Londrina, 1994. 49 p.

INSTITUTO BRASILEIRO DE GEOGRAFIA E ESTATÍSTICA - IBGE. Produção agrícola municipal: culturas temporárias e perenes. Prod. Agríc. Municipal, 39:1-101, 2012.

JACQUES, R.A.; ARRUDA, E.J.; OLIVEIRA, L.C.S.; OLIVEIRA, A.P.; DARIVA, C.; OLIVEIRA, J.V. \& CARAMÃO, E.B. Influence of agronomic variables on the macronutrient and micronutrient contents and thermal behavior of mate tea leaves (Ilex paraguariensis). J. Agric. Food Chem., 55:7510-7516, 2007.

KAMINSKI, J.; MOTERLE, D.F.; RHEINHEIMER, D.S.; GATIBONI, L.C. \& BRUNETTO, G. Potassium availability in a Hapludalf soil under long term fertilization. R. Bras. Ci. Solo, 34:783-791, 2010.
LOURENÇO, R.S.; MEDRADO, M.J.S. \& DALZOTO, D.N. Efeito de níveis de potássio sobre a produtividade de ervamate (Ilex paraguariensis St. Hil.) no município de Ivaí, PR. Bol. Pesq. Flor., 39:119-131, 1999.

MEJÍA, E.G.; SONG, Y.S.; HECK, C.I. \& RAMÍREZ-MARES, M.V. Yerba mate tea (Ilex paraguariensis): Phenolics, antioxidant capacity and in vitro inhibition of colon cancer cell proliferation. J. Funct. Foods, 2:23-34, 2010.

MONTECHIESI, R. Yerba mate, câmbios em la producción, no em la actividad. Posadas, 2008. 62p.

NEVES, L.S.; ERNANI, P.R. \& SIMONETE, M.A. Mobilidade de potássio em solos decorrente da adição de doses de cloreto de potássio. R. Bras. Ci. Solo, 33:25-32, 2009.

OLIVEIRA, Y.M.M. \& ROTTA, E. Área de distribuição natural da erva-mate (Ilex paraguariensis St. Hil.). In: SEMINÁRIO SOBRE ATUALIDADES E PERSPECTIVAS FLORESTAIS. Silvicultura da erva-mate (Ilex paraguariensis St. Hil.). 1983, Curitiba. Anais... Curitiba, Embrapa/CNPF, 1985. p.17-36.

OLIVEIRA, R.H.; ROSOLEM, C.A. \& TRIGUEIRO, R.M. Importância do fluxo de massa e difusão no suprimento de potássio ao algodoeiro como variável de água e potássio no solo. R. Bras. Ci. Solo, 28:439-445, 2004.

PANDOLFO, M.C.; FLOSS, P.A.; Da CROCE, D.M. \& DITTRICH, R.C. Resposta da erva-mate (Ilex paraguariensis St. Hil.) à adubação mineral e orgânica em um Latossolo Vermelho aluminoférrico. Ci. Flor., 13:37-45, 2003.

PREZOTTI, L.C. Fertilização do cafeeiro. In: ZAMBOLIM, L. Tecnologias de produção de café com qualidade. Viçosa, MG, Universidade Federal de Viçosa, 2001. p.607-615.

RADOMSKI, M.I.; SUGAMOSTO, M.L.; GIAROLA, N.F.B. \& CAMPIOLO, S. Avaliação dos teores de macro e micronutrientes em folhas jovens e velhas de erva-mate nativa. R. Inst. Flor., 4:453-456, 1992.

RAIJ, B.van. Fertilidade do solo e adubação. Piracicaba, Ceres, 1991. 343p.

RAKOCEVIC, M.; BORSATO, A.V.; BONA, C. \& MEDRADO, M.J.S. Distribuição de estômatos em folhas de diferentes idades de erva-mate cultivada em monocultura e subbosque. In: CONGRESO SUDAMERICANO DE LA YERBA MATE, 5., Posadas, 2011. Actas... Posadas, INYM/ INTA/INaM, 2011. p.45-50.

REISSMANN, C.B.; KOEHLER, C.W.; ROCHA, H.O. \& HILDEBRAND, E.E. Avaliação da exportação de macronutrientes pela exportação da erva-mate. In: SEMINÁRIO SOBRE ATUALIDADES E PERSPECTIVAS FLORESTAIS. Silvicultura da erva-mate (Ilex paraguariensis St. Hil). Curitiba, 1985. Anais... Curitiba, Embrapa/CNPF, 1985. p.128-139.

REISSMANN, C.B.; ROCHA, H.O.; KOEHLER, C.W.; CALDAS, R.L.S. \& HILDEBRAND, E.E. Bio-elementos em folhas e hastes de erva-mate (Ilex paraguariensis $\mathrm{St}$. Hil.) sobre Cambissolo na região de Mandirituba - PR. Floresta, 14:49-54, 1983. 
ROSA, G.N.G.P. Sistema de recomendação de corretivos e fertilizantes para o cultivo do coqueiro. Viçosa, MG, Universidade Federal de Viçosa, 2002. 76p. (Dissertação de Mestrado)

ROSOLEM, C.A.; GARCIA, R.A.; FOLONI, J.S.S. \& CALONEGO, J.C. Lixiviação de potássio no solo de acordo com suas doses aplicadas sobre palha de milheto. R. Bras. Ci. Solo, 30:813-819, 2006.

SANTIN, D. Produtividade, teor de minerais, cafeína e teobromina em erva-mate adensada e adubada quimicamente. Curitiba, Universidade Federal do Paraná, 2008. 114p. (Dissertação de Mestrado)

SANTOS, F.C. Sistema de recomendação de corretivos e fertilizantes para a cultura da soja. Viçosa, MG, Universidade Federal de Viçosa, 2002. 64p. (Dissertação de Mestrado)
SATTERTHWAITE, F.E. An approximate distribution of estimates of variance components. Biom. Bull., 2:110$114,1946$.

TEDESCO, J.M.; GIANELLO, C.; BISSANI, C.A.; BOHNEM, H. \& VOLKWEISS, S.J. Análise de solo, plantas e outros materiais. 2.ed. Porto Alegre, Universidade Federal do Rio Grande do Sul, 1995. 174p. (Boletim Técnico, 5)

TEIXEIRA, L.A.J.; SPIRONELLO, A.; FURLANI, P.R. \& SIGRIST, J.M.M. Parcelamento da adubação NPK em abacaxizeiro. R. Bras. Frutic., 24:219-224, 2002.

van KEULEN, H. Graphical analysis of annual crop response to fertilizer application. Agric. Syst., 9:113-126, 1982.

WERLE, R.; GARCIA, R.A. \& ROSOLEM, C.A. Lixiviação de potássio em função da textura e da disponibilidade do nutriente no solo. R. Bras. Ci. Solo, 32:2297-2305, 2008. 